\title{
SISTEM PERTANGGUNGJAWABAN PELAKSANAAN APBD 2017 PADA BADAN PENGELOLAAN KEUANGAN DAN ASET DAERAH PROVINSI NTB
}

\author{
Henni Comala Hikmi \\ ASM Mataram \\ comala.hikmi@gmail.com
}

\begin{abstract}
Abstrak - Judul dari penelitian adalah Sistem Pertanggungjawaban Pelaksanaan APBD 2017 Pada Badan Pengelolaan Keuangan dan Aset Daerah Provinsi NTB. Penelitian ini bertujuan untuk mengetahui Sistem Pertanggungjawaban Pelaksanaan APBD 2017 Pada Badan Pengelolaan Keuangan dan Aset Daerah Provinsi NTB. Penelitian ini bermanfaat untuk menjadi referensi bagi peneliti selanjutnya, sebagai bahan masukan bagi Badan Pengelolaan Keuangan dan Aset Daerah Provinsi NTB. Dalam menentukan langkah-langkah kebijakan yang akan datang, dan dapat memenuhi salah satu syarat guna menyelesaikan konsentrasi studi pada program studi manajemen administrasi Akuntansi. Jenis penelitian yang digunakan dalam penelitian ini yaitu jenis penelitian deskriftif. Adapun teknik pengumpulan data dari penelitian ini berupa teknik wawancara, teknik observasi, dan teknik dokumentasi. Jenis data yang digunakan adalah data kuantitatif dan data kualitatif serta sumber data dari peneliti berupa data primer dan data sekunder. Berdasarkan hasil penelitian yang dilakukan penulis menyimpulkan Sistem Pertanggungjawaban Pelaksanaan APBD 2017 Pada Badan Pengelolaan Keuangan dan Aset Daerah Provinsi NTB cukup efektif. Hal ini terlihat dari sistem pertanggungjawaban pelaksanaan APBD 2017 nya dari kinerja pihak-pihak yang terkait dan langkah- langkah atau tahapan-tahapan dari prosedur pertanggungjawabannya sehingga menjadi buku Laporan Keuangan Pemda dari semua SKPD untuk Anggaran tahun 2017.
\end{abstract}

Kata Kunci : Sistem Pertanggungjawaban, Pelaksanaan APBD 2017.

\section{PENDAHULUAN}

A. Latar Belakang

Untuk mengatur kegiatan pemerintah daerah, maka suatu daerah harus membuat Anggaran Pendapatan dan Belanja Daerah (APBD). Anggaran Pendapatan Dan Belanja Daerah (APBD) merupakan rencana keuangan tahunan pemerintah daerah yang dibahas dan disetujui bersama oleh pemerintah daerah dan DPRD dan ditetapkan dengan peraturan daerah (Perda). APBD disusun oleh Badan Eksekutif (pemerintah Provinsi NTB), dan Legislatif (DPRD). Salah satu tujuan dibuat anggaran adalah untuk membiayai seluruh belanja rutin pegawai dan kegiatan public dalam rangka meningkatkan kesejahteraan rakyat. Selanjutnya tahap pelaksanaan APBD adalah proses pelaksanaan pembiayaan pembangunan yang dilakukan oleh pemerintah Provinsi selama tahun anggaran berjalan. Setelah tahap pelaksanaan ini kemudian dilanjutkan dengan proses pertanggungjawaban yang dilakukan oleh Gubernur kepada DPRD Provinsi untuk diberikan penilaian. Bentuk utama pertanggungjawaban pelaksanaan APBD adalah adanya kewajiban pemerintah Daerah sebagai pengguna anggaran untuk membuat laporan keuangan dan laporan kinerja yang kemudian akan dievaluasi dan diklarifikasi oleh BPK, DPRD dan Kementerian Dalam Negeri.
Badan Pengelolaan keuangan dan Aset Daerah telah melaksanakan proses penganggaran sesuai dengan Peraturan Daerah (Perda) yang berlaku, yang selanjutnya pelaksanaannya di pertanggung jawabkan dalam bentuk pertanggungjawaban pelaksanaan APBD, yang dalam hal ini adalah petanggungjawaban pelaksanaan APBD 2017.

Berdasarkan latar belakang di atas dapat diketahui bahwa pertanggungjawaban pelaksanaan APBD mempunyai peranan yang penting dalam kegiatan operasional pemerintah. Oleh sebab itu penulis tertarik untuk membuat laporan penelitiandengan judul "SISTEM PERTANGGUNGJAWABAN PELAKSANAAN APBD 2017 PADA BADAN PENGELOLAAN KEUANGAN DAN ASET DAERAH PROVINSI NTB"

\section{B. Rumusan Masalah}

Berdasarkan latar belakang masalah yang telah diuraikan diatas, maka rumusan masalah dalam Laporan Penelitianini adalah Bagaimana Sistem Pertanggungjawaban pelaksanaan APBD 2017 Pada Badan Pengelolaan Keuangan Dan Aset Daerah Provinsi NTB"

\section{Tujuan penelitian}

Berdasarkan perumusan masalah yang ada, maka tujuan yang ingin dicapai dari hasil 
Laporan Penelitianini adalah untuk mengetahui dan memahami Sistem Pertanggungjawaban pelaksanaan APBD 2017 Pada Badan Pengelolaan Keuangan Dan Aset Daerah Provinsi NTB.

D. Manfaat Penelitian

Adapun manfaat Laporan Penelitian ini adalah sebagai berikut:

\section{Manfaat Teoritis}

Hasil Penelitian Penelitianini diharapkan dapat bermanfaat terhadap perkembangan ilmu pengetahuan khususnya yang terkait dengan Sistem Pertanggungjawaban pelaksanaan APBD Provinsi NTB.

\section{Manfaat Praktis}

Hasil Laporan Penelitian ini diharapkan menjadi bahan pertimbangan dalam mengelola atau menetapkan kebijaksanaan yang terkait dengan Sistem Pertanggungjawaban pelaksanaan APBD Provinsi NTB.

E. Pengumpulan Data

1. Teknik Pengumpulan Data

Adapun teknik pengumpulan data yang penulis gunakan dalam penelitian ini adalah sebagai berikut :

a. Observasi ( Pengamatan)

Merupakan Suatu teknik atau cara mengumpulkan data dengan jalan mengadakan pengamatan terhadap kegiatan yang sedang berlangsung. (Sukmadinata, 2013:220)

b. Wawancara (Interview)

Merupakan salah satu bentuk teknik data yang banyak digunakan dalam penelitian deskriptif kualitatif dan deskriptif kuantitatif, wawancara dilakukan secara lisan dalam pertemuan tatap muka secara individual. (Sukmadinata, 2013:216)

c. Dokumentasi

Dokumentasi merupakan suatu teknik pengumpulan data dengan menghimpun dan menganalisis dokumen-dokumen tertulis, gambar maupun elektronik. Sukmadinata, 2013:221)

\section{F. Jenis Data Penelitian dan Sumber Data}

\section{Jenis Data Penelitian}

Adapun jenis data yang digunakan dalam penelitian ini adalah jenis data kualitatif dan jenis data kuantitatif.

\section{a. Data Kualitatif}

Data Kualitatif adalah data yang berbentuk kata, kalimat skema dan gambar (Sugiyono, 2013:23).

b. Data Kuantitatif

Data Kuantitatif adalah data yang berbentuk angka atau data kualitatif yang diangkakan. Data kualitatif yang diangkakan (skoring) misalnya terdapat dalam skala pengukuran. (Sugiyono, 2013:23).

\section{Sumber Data}

Adapun sumber data yang penulis gunakan dalam penulisan Penelitian ini adalah sebagai berikut:

\section{a. Data Primer}

Sumber primer adalah sumber data yang langsung memberikan data kepada pengumpul data (Sugiyono, 2017:237).

\section{b. Data Sekunder}

Sumber sekunder adalah sumber yang tidak langsung memberikan data kepada pengumpul data misalnya lewat orang lain atau lewat dokumen (Sugiyono, 2017:137).

\section{G. Metode Analisis Data}

Teknik analisis data dalam penelitian ini adalah statistik Deskriptif, yaitu statistik yang digunakan untuk menganalisis data dengan cara mendeskripsikan atau menggambarkan data yang telah terkumpul sebagaimana adanya tanpa bermaksud membuat kesimpulan yang berlaku untuk umum atau generalisasi. (Sugiyono, 2017 : 147)

\section{Kajian Pustaka}

A. Sistem

\section{Pengertian Sistem}

Ada beberapa pengertian sistem dilihat dari sudut pandang yang berbeda (Sujarweni, $2015: 1$ ) yaitu :

a. Pengertian sistem dilihat dari prosedur atau kegiatannya

Sistem adalah suatu rangkaian prosedur atau kegiatan yang dibuat untuk melaksanakan program perusahaan. Sistem merupakan serangkaian kegiatan dalam prosedur-prosedur atau elemenelemen yang saling berkaitan atau berhubungan antara satu dengan yang 
lainnya dan tidak bisa dipisahkan (Basuki, 2011: 7 dalam Tamala).

Jadi dapat disimpulkan bahwa sistem merupakan serangkaian kegiatan yang saling berkaitan satu dengan yang lainnya dan bekerja sama untuk mencapai tujuan tertentu.

\section{B. Pertanggungjawaban}

Menurut Mustopadidjaja(2003), pertanggungjawaban merupakan ujung dari siklus anggaran, setelah perencanaan dan pelaksanaan. Inti dalam pertanggungjawaban adalah evaluasi, evaluasi kinerja, dan akuntabilitas. Dalam mempertanggungjawabkan keuangan Negara yang dipercayakan Rakyat, Pemerintah menggunakan Laporan Keuangan sebagai alat pertanggungjawaban.

\section{Pelaksanaan}

Pelaksanaan adalah suatu tindakan atau pelaksanaan dari sebuah rencana yang sudah disusun secara matang dan terperinci, implementasi biasanya dilakukan setelah perencanaan sudah dianggap siap. Sederhana pelaksanaan bisa diartikan penerapan.

\section{Anggaran Pendapatan Dan belanja Daerah (APBD)}

Berdasarkan pasal 64 ayat (2) UU Nomor 5 tahun 1974 tentang pokok-pokok pemerintahan daerah, maka APBD dapat didefinisikan sebagai rencana operasional keuangan pemda, dimana pada satu pihak menggambarkan perkiraan pengeluaran setinggi-tingginya guna membiayai kegiatankegiatan dan proyek-proyek daerah selama satu tahun anggaran tertentu, dan di pihak lain menggambarkan perkiraan dan sumbersumber penerimaan daerah guna menutupi pengeluaran-pengeluaran yang dimaksud (Mamesah, 1995: 20).

3. HASIL

\section{A. Gambaran Umum BADAN PENGELOLAAN KEUANGAN DAN ASET DAERAH NTB}

1. Sejarah Badan pengelolaan keuangan dan aset daerah (BPKAD) Provinsi NTB

Badan Pengelolaan Keuangan Daerah Provinsi Nusa Tenggara Barat atau yang lebih dikenal dengan BPKAD Provinsi NTB merupakan gabungan dari eks Bagian Perlengkapan pada Biro Umum Setda Provinsi Nusa Tenggara Barat dan eks Biro Keuangan Setda Provinsi Nusa Tenggara Barat. Diharapkan dengan penggabungan tersebut dapat lebih memudahkan dalam menyelesaikan permasalahan asset maupun keuangan yang sangat kompleks.Terlebih beberapa urusan di Kabupaten/Kota akan diserahkan urusannya kepada Pemerintah Provinsi dalam pengelolaan keuangan dan aset

BPKAD Provinsi NTB merupakan Satuan Kerja Perangkat Daerah baru yang dibentuk berdasarkan Peraturan Gubernur Nomor 22 Tahun 2015 tentang Perubahan Kedua Atas Peraturan Gubernur Nomor 22 Tahun 2008 tentang Rincian Tugas, Fungsi dan Tata Kerja Inspektorat, bappeda dan Lembaga Teknis Daerah Provinsi Nusa Tenggara Barat dimana BPKAD Provinsi NTB merupakan bagian dari pada Lembaga Teknis Daerah.

\section{Visi dan misi}

Visi BPKAD adalah menjadi institusi pengelola keuangan dan asset daerah terbaik.

\section{Misi BPKAD NTB adalah:}

a. Melaksanakan fungsi sebagai PPKD dengan penuh amanah dan profesional

b. Mengikhtiarkan laporan keuangan pemerintah provinsi NTB tetap wajar tanpa perkecualian (WTP) setiap tahunnya

c. APBD dapat di implementasikan sesuai kondisi masyarakat dan sinkron dengan APBD Kabaten/Kota serta APBN

d. Mempercepat penyelesaian tindak lanjut laporan hasil pemeriksaan.,

e. Melaksanakan fungsi pengelolaan BMD dengan tertib dan optimal dalam peningkatan pendapatan asli daerah serta Penguatan kelembagaan dan SDM BPKAD yang berkualitas dan melayani.

\section{3. tugas dan fungsi}

Sebagai Lembaga Teknis Daerah, BPKAD mempunyai tugas membantu Gubernur dalam melaksanakan penyusunan dan kebijakan daerah di Bidang Pengelolaan Keuangan dan Aset. 
Dalam melaksanakan tugas dimaksud BPKAD menyelenggarakan fungsi :

a. Perumusan kebijakan teknis di bidang pengelolaan keuangan dan aset,

b. Penyusunan laporan neraca pengelolaan keuangan dan asset daerah sesuai dengan peraturan perundang-undangan,

c. Pengkoordinasian dan pembinaan pelaskanaan tugas di bidang pengelolaan keuangan dan aset,

d. Pemberian dukungan atas penyelenggaraan pemerintahan daerah di bidang pengelolaan keuangan dan aset,

e. Penyelesaian sengketa aset,

f. Pengendalian dan evaluasi pelaskanaaan tugas di bidang pengelolaan keuangan dan aset,

g. Pengendalian dan evaluasi pelaksanaan tugas di bidang pengelolaan keuangan dan aset,

h. Pembinaan dan pengawasan penyelenggaraan pengelolaan keuangan dan asset daerah kabupaten/kota sesuai peraturan perundang-undangan, dan

i. Pelaksanaan tugas lain yang diberikan oleh atasan.

\section{Susunan organisasi}

Berdasarkan pasal 5 Pergub Nomor 51 Tahun 2016 dikatakan bahwa dalam melaksanakan fungsinya, BPKAD Provinsi NTB memiliki susunan organisasi terdiri dari:
a. Kepala Badan,
b. Sekretariat,
c. Bidang Anggaran,
d. Bidang Perbendaharaan,
e. Bidang Akuntansi dan

f. Pelaporan dan Unit PelaksanaTeknis Badan (UPTB).

\section{PEMBAHASAN}

A. Sistem Pertanggungjawaban Pelaksanaan APBD 2017 Pada Badan Pengelolaan Keuangan Dan Aset Daerah (BPKAD) Provinsi NTB

1. Pihak-pihak yang bertanggung jawab terhadap Anggaran dan Pendapatan Daerah (APBD)

a. Pihak eksekutif (Kepala daerah, Sekretaris Daerah, Tim Anggaran, SKPD, Bappeda, dan DPKD).

b. Pihak Legislatif

Pihak Legislatif yang terlibat dalam penyusunan anggaran pemerintahan daerah, antaralain : Panitia Anggaran Legislatif, Komisi-komisi DPRD.

c. PihakPengawas (Auditor).

Pihak pengawas dalam perencanaan dan pengelolaan keuangan daerah yang terlibat dalam pertanggungjawaban terhadap APDB, antara lain: Badan Pemeriksa Keuangan (BPK), Badan Pengawasan Keuangan dan Pembangunan (BPKP), Inspektorat Daerah.

2. Prosedur Pertanggungjawaban Anggaran Pendapatan dan Belanja Daerah (APBD)

a. Laporan Realisasi Semester Pertama Anggaran Pendapatan dan Belanja

Kepala SKPD lingkup Pemerintah Provinsi NTB menyusun laporan realisasi semester pertama anggaran pendapatan dan belanja SKPD sebagai hasil pelaksanaan anggaran yang menjadi tanggung jawabnya. Pejabat pengguna anggaran masingmasing SKPD menyampaikan laporan realisasi semester pertama dan kedua anggaran pendapatan dan belanja SKPD.

Berdasarkan data hasil penelitian berupa Laporan Realisasi Anggaran, LRA dapat disampaikan dalam uraian berikut.

b. Laporan Tahunan

Berdasarkan penjelasan dari kasubbid Pelaporan, Laporan Tahunan/Laporan 
Keuangan disiapkan oleh PPK BPKAD Provinsi NTB selaku SKPKD.

c. Penetapan

Raperda

Pertanggungjawaban Pelaksanaan APBD

Laporan Keuangan

Sebagai pertanggungjawaban

pelaksanaan APBD kepada Badan

Pemeriksaan Keuangan Perwakilan

NTB untuk dilakukan pemeriksaan lebih lanjut.

Berdasarkan hasil Pemeriksaan BPK selanjutnya Gubernur Provinsi NTB memberikan Tanggapan dan Penyesuaian atas laporan Keuangan.

d. Evaluasi Rancangan Peraturan Daerah tentang Pertanggungjawaban Pelaksanaan APBD dan Peraturan Kepala Daerah tentang Penjabaran Pertanggungjawaban Pelaksanaan APBD

Hasil evaluasi rancangan peraturan daerah tentang pertanggung jawaban pelaksanaan APBD dan rancangan peraturan gubernur tentang penjabaran pertanggungjawaban pelaksanaan APBD sudah sesuai dengan kepentingan umum dan peraturan perundang-undangan, maka Gubernur menetapkan rancangan peraturan daerah dan rancangan peraturan gubernur menjadi peraturan daerah dan peraturan Gubernur.

\section{KESIMPULAN}

Berdasarkan uraian mengenai sistem pertanggungjawaban Pelaksanaan Anggran Pendapatan dan Belanja daerah (APBD) 2017 Pada Badan Pengelolaan Keuangan dan Aset Daerah Provinsi NTB maka peneliti dapat mengambil kesimpulan sebagai berikut:

1. Pihak-pihak yang bertanggung jawab terhadap Anggaran dan Pendapatan Daerah (APBD) yaitu : Pihak eksekutif, Pihak Legislatif, Pihak Pengawas (Auditor).

2.

rosedur Pertanggungjawaban Anggaran Pendapatan dan Belanja Daerah (APBD) yaitu : Laporan Realisasi Semester Pertama,Anggaran Pendapatan dan Belanja, Laporan Tahunan, Penetapan Raperda Pertanggungjawaban Pelaksanaan APBD, Evaluasi Rancangan
Peraturan Daerah tentang Pertanggungjawaban Pelaksanaan APBD dan Peraturan Kepala Daerah tentang Penjabaran Pertanggungjawaban Pelaksanaan APBD.

\section{DAFTAR PUSTAKA}

Sugiyono, 2017. Metode penelitian kuantitatif, kualitatif, $\mathrm{R}$ \& D,Alfabeta:Bandung

Sukmadinata, Nana Syaodih, 2013. Metode penelitian Pendidikan Bandung: PT. Remaja Rosdakarya.

Sujarweni, 2015.Sistem Akuntansi.Yogyakarta: Pustaka Baru Press

Basuki, 2011.Sistem Akuntansi. Yogyakarta: dalam Tamala

Halim, 2007. Akuntansi keuangan daerah. Jakarta: Salemba Empat

Halim, 2004. Manajemen keuangan daerah. Jogyakarta

http://www.academia.edu/8639345/LAPO RAN PERTANGGUNGJAWABAN KEUA NGN

http://digilib.unila.ac.id/4718/11/BAB\%20II .pdf

http://slideplayer.info/slide/12260885/ 